\title{
Capitalizing Genius Albert Einstein's Idea for Reformation of Educational Systems for Producing Genius Gentry
}

\author{
Yadav $\mathrm{RC}^{1 *}$ and Iadav $\mathrm{J}^{2}$ \\ ${ }^{1}$ Water and Environment interaction Specialist, India \\ ${ }^{2}$ Head PhD. Studies, Amity Business School, Amity University, Uttar Pradesh, India
}

*Corresponding author: Yadav RC, Water and Environment interaction Specialist, ICAR Research Centre Agra, India, Email: ramcyadav@rediffmail.com

\section{Research Article}

Volume 4 Issue 1

Received Date: February 22, 2020

Published Date: March 27, 2020

\section{Abstract}

Importance of creating a hook in mind for quick grasp of knowledge is known for long time as a psychological advancement. However, there is no such known way to raise ability of minds of gentry, in general. This study takes support of genius Einstein's idea to live with problem for long time to find solutions. Results of changes in educational system from Primary School, Secondary Schools, University - UG and PG and PhD were considered to take lessons and make recommendation of esteem values. Lot of changes viz trimesters, semesters annual terms have been tried and reformed, thus, different patterns of duration of education systems, subjects, their syllabus and examination patterns are in prevalence, each one putting their justifications. Study conducted taking changes that had been brought and studied for almost six decades (1960 till present time with new theme of remaining with problem and finding solutions and substantiation enabled finding a good logical and exact solution for the variable duration and allied patterns. Substantiation with new beginning made at low professional level and citing other two examples of innovations in indigenous natural resources management serve scientific support for the worthiness of the hypothesis. It was concluded that educational systems should maintain system to let subjects being studied in classes remain in revision for long time so that it gets absorbed in mind that produces genius gentry. Hence, irrespective of the systems and levels of education systems the duration patterns viz trimester, semester and annual systems should have annual examination as final examination covering entire syllabus. This system will produce strong impression in human mind to remain for longer than that with short trimester and semester systems and will produce genius gentry for the nations.

Keywords: Competitive examinations; Education in county and genius gentry; Intellectual properties; National socioeconomic prosperity and primary; Secondary and University educations reformations

\section{Introduction}

Education is a social and governments main sector of responsibilities after fresh air, food, and sanitation. Many changes have been brought as per wisdom of the exiting governances since long past. The changes have produced good and bad effects which have been realized by the people in both the developed and developing countries. Depending on the realizations of good and poor effects several reformations have been introduced. Degree programmes on educations different durations are being adapted to improve teaching and a system of teaching -learning is emphasized in different part of world. However, there has been lack of sound basis for bringing such modus operandi to bring an effective result for which the education systems are created. One such issue is the duration for studies viz trimester, (having three final examinations per year, semesters having two final examinations and the annual having one final examination) has been prevailing which requires a unique system to be created. Such patterns of trimesters' examinations had been 
adopted in Agricultural Universities, which were brought in American pattern of examinations right in 1960; for example the then Uttar Pradesh Agricultural University, now under its changed name Gobind Vallabh Pant University of Agriculture and Technology, Pant Nagar in Nanital district before creation of separate state of Uttarakhand, of united Uttar Pradesh, India. The University was based on land grant with initial 1600 acre farm in Tarai Region, which was started with trimester based examinations for all courses of different degree durations. Seeing the successes of the pattern it became a wave to establish similar universities, may be the land grant pattern exist or not in almost all states of countries. Now many universities have been established in India and abroad to create social justice in countries. There have been transformations in duration with individual circumstantial justification to those changes; hence it has become an aspect which needs consideration for bringing a unique pattern from trimester to semester or even to annual. However, there is lack of visible solid justification for such reformations.

Albert Einstein, the brilliant scientist, who is now every one's idea of an absolute genius, who had concluded that acceleration (speeding up) of an object such as machine bends time and space through which it travels, which provided new scientific basis of ecological changes at different locations in spatial and temporal position in globe. Elbert Einstein also said that people think that I am genius, but the fact is that I live with problem for longer time. This fact is taken up to explore and create reformation of educational systems that creates mandatory provision to remain in contact of syllabus and revision to produce genius generations. Objective of this study was to analyze the educational system taking scenarios for six decade's developments in India and find a unique system to create sharpness of minds to produce genius gentry in nations. The results of the study will improve efficiency of educational systems, without further incurring extra burden on country's economy for which lot of efforts, time and budgets have been getting spent, The development of genius gentry will bring several social capital and intellectual properties in different areas.

\section{Materials and Method}

\section{Genius Albert Einstein's Short Biography}

Born on March 14, 1879 in ULM, Germany as first healthy child to Pauline and her husband Harmaan, creating a very delighted parents. The father Hermaan was an electrical engineer at the time when electrical products were new and exciting area to work in. Next year the Harmaan family moved to Munic to team up with his brother Jacob to start makeup of electrical equipments. The child grew with his parent's given name Albert and became great scientist Albert Einstein.
Albert Einstein realized a different way; he added a new dimension to space -environment $\left(\mathrm{L}^{3}\right)$, the time as fourth dimension. The gravity and acceleration bend the time; then the bent time will be slower than straight time. The Sun rays travelling in straight line will reach fast; so in theory an astronaut finds everyone has become aged while he is not. This is explained by the theory of relativity given by Albert Einstein [1]. The environment with three l (Length, Width, Height) with time as fourth dimension i.e, as the bent time It is this space -time which is actually bent by gravity and acceleration distorting space and time.

AlbertEinstein'stheory ofrelativity turnedunderstanding of universe. He wrote his discoveries and conclusions in two separate papers: The special theory of relativity in 1905 at the age of 26 years and a general theory of relativity in 1916 i.e. after 37 years. In his special theory he presented infamous equation $\mathrm{E}=\mathrm{m} \mathrm{c}^{2}$; where $\mathrm{E}$ is energy, $\mathrm{m}$ is mass and c is speed of light. The speed of light is 299,792,458 m/s. His works later modified some of Newton's laws on which many modern science and technological advancements are based. Many researches went on space time to find various implications.

Following Second World War the famous Albert Einstein who was by then working in the USA, got worried that Germans might discover a way of nuclear fission to make a new type of bomb. [There are two ways of starting nuclear reactions -the process of creating radiations and freezing atom's incredible power] [1]. The first one is called fission, which was discovered by German Otto Haan and Austrian Lise in the 1930s, they worked together but following other Otto this time Otto Frish Hahn the rise of Nazism, Metiner fled to Sweeden to avoid persecution, because she had been classified Jewish, The collaboration resulted in Hahan revealing the discovery of fission to the world in 1938, that was when neutrons were fired at a nucleus, causing it to break in to at least two parts, incredible energy was released. By 1942 Italian born Enrico Fermi had built a nuclear reactor in Chicago generating electricity with fission, it was the first in the world]. Albert developed type of hydrogen bomb named A-bomb. Following dropping of the bomb on Japanese City Hiroshima on August 5, 1945, Germany, Japan's alley had already surrendered. Other A bomb was dropped on Nagasaki on August 9. By August 14 Japanese had surrendered and the war was over. Many Japanese who survived blast had died of radiation burns and sickness, the result of nuclear fallout. The tragedy made impact on minds of people that the hydrogen bombs are used for peaceful purposes and applications in social welfare measures. Thus, Albert Einstein had good background and opportunity to understand and work in his area of interest for long time and made numerous discoveries which changed the world. 


\section{General Scenario of Educational Systems}

During the ancient time education was imparted by Kulgurus and disciples based teaching learning and practicing were created, which has been depicted in mythologies. As civilization grew educations of organized systems emerged and people got educated both vertical and horizontal domain. There had been systems of primary, secondary (High schools and intermediate colleges) and various degree programmes of teaching of under graduate, post graduate and $\mathrm{PhD}$, diploma courses etc, which generally had been of annual pattern ie teaching of a prescribed syllabus and taking final examinations at end on annual basis.

A case is cited when a new system of university education was introduced from United States of America in 1960, which was different from the old existing system of education. First it had trimesters completing sessions in three months and ending with final examinations of all course during the trimesters. Many leading states in India, particularly in northern India started such Agricultural Universities and it became a trend to establish such universities in almost all the states of country. Even people had demanded an agricultural university in different regions as symbol of social justice of providing equal opportunity for the development of agriculture and society. On the other hand developments had been created and Ministry of Agriculture and Rural development as an apex body of research named as Indian Council of Agricultural Research had been established. For taking such reformations a University Grant commission has been organized which is funding the universities and teaching and research in other subjects. In all the systems of education, conventional and advanced agriculture and technologies. There are mixed systems of trimesters, semesters and annual and there has been no sound footing based development in education systems. The education systems had been run with one's own justification and patterns of durations and examination etc.

\section{Hypothesis}

It is well understood fact that creating a hook in mind makes pupil understands a lesson being taught in class rooms. For making things fully come to mind many innovations in teachers' education are being created and brought to practice lesson imparted. Even some states have created university of teachers' education. But, there has been no research on impact of the system on development of genius gentry so that intelligentsia develops in the mind. The educated mass will be encountering some specific works and projects. Intelligentsia will be able to absorb and bring some creativity as revealed by biography of Albert Einstein. Results of intelligence should be visible in results of completive examinations. The results of passing out or producing merit should work as index for genius produced by educational system organizations. Thus, it demands creating system where the course content gets revised for longer duration say for at least for entire year. This long duration in touch of the students should be brought in education system.

\section{The Technology Module}

The education system should be created that irrespective of the duration of the terms of education, be it trimester, semester or even annual should have a final examination coving entire syllabus, which had been covered under different duration to form syllabus for the annual and final examinations. This system will keep the subject under revision; make deep dent in mind and will come fastin memory when there is requirement of finding a solutions, thus the three will be increase in score and reflection of genius level of the student group. In this systems responsibility will be to find important and likely questions that might appear in the final examinations and composite effect will be that students will be to make high score and high rates of selection. Thus, intelligentsia being cultivated by the teaching institution will produce genius gentry.

\section{Modus Operandi}

There can be several justifications in adoption of system via trimesters, semesters or annual systems which have been going in their own way. This new system of conducting final examination in sub sections or in wholesome final examinations for the years should be conducted in final annual examination. This pattern will completely supplement the genius Albert Einstein and fulfill needed aspect to produce genius gentry. As the subject will be kept in revision for entire year it will make good impact and the subject will stand in memory for long time. The subject teachers either singly or jointly should set question paper for the final examination that will bring seriousness about subject and examination. The net effect will be that student's will adapt the subject and perform better in competitive examinations than what it is being observed in the different existing systems of varying patterns. This system will help the students get prepared for joint competitive examinations. The student passing such examination will have deep thinking in the subject and make visible difference in thinking about the problems that they will be facing in their life. There will be different aptitude in the gentry that will produce different enhanced delivery of the tasks that they will be perfuming in their assignments.

As teachers will devote their valuable experience based time in setting question papers and examinations, there will be better interaction and seriousness between the teachers and students. There will be development of better disciple in the educational institutions that what has existed at present. 
The institution should develop such working arrangements by creating some awarding avenues for performers viz grant of increment and or promotion etc. The degree of genius's produced and performance by the classes will serve as performance indicators.

\section{Results}

\section{General}

As brought out earlier there are various patterns of durations and examinations pattern. However there is no unified solid thinking and justification based thinking for system that long time of contact remains in the system. One such system has been fixed for the Industrial training institute course (ITI) where in addition of various courses the final examination is held annually at the end of year. This pattern fulfills condition students remain in touch of syllabus. Hence, it is fulfilling the requirement as per thinking of Einstein. The ITI is basic course which takes admission of after High School or Intermediate Examinations, and keep long time revision of the subject under syllabus. The course is highly practical and theory and practical make the low understanding group become conversant. It is logical to think that this system will be highly suitable for classes when candidates are grownup and studying details of theory and practice.

\section{Adoption of the New Module}

As brought out in introduction there have been different patterns of conducting teaching and examinations viz, trimesters, semesters and annual yearly examinations. There is no existing system as synthesized or being practiced even today, in spite of lot of reformations have been brought in educational patterns in diploma, UG, PG course programmes. Only one remarkable change has been brought in after semester to have final examinations for both the semester I and II at the end of year as final examinations. The long contact of course content and time to time revisions gives opportunity to think and creates ability to make some alternative reformations. Since the ITI's are the very basic courses, good effects have been realized in making confidence in gray or blue collar jobs. As such innovations cannot be expected from such beginners in the respective profession. Nevertheless, this change serves as good example for supplementing the worthiness of the hypothesis made in this study. It warrants making detailed study on such development of genius gentry based changed results for which detailed national data based survey will emerge in due course of time, by studies that will get conducted on this aspects.

\section{Competitive Examinations and Crash Course}

In the increasing population and emphasis of education lot of graduate both Government colleges and numbers of private institutions have been opened by which no of graduate etc. have tremendously increased. There has become rush for getting selected a for PG studies or for employments. There can be crash course and preparatory courses in the country. Lot of efforts and expenditure have gone in populous country such as India, but the reformations based on the hypothesis created in the present study have not emerged. There can be good scores by the students in classes, but no resulting reveal of genius gentry and discoveries. Some advancement are seen in day today life, but it is being brought from somewhere else, because knowledge on such subjects are transferable. Such developments viz on information technologies (IT) and computer science have been global phenomena and it will be unfair to claim the advancements in any country in particular, to the levels revealed by the biography of genius Albert Einstein. Such patterns as brought out as technology module i.e. in the pattern of teaching and examinations of the ITI's have yet to come to minds of policy makers and implementers.

\section{Unique Indigenous Genius Development in Agriculture}

In this section two example cases are presented which have created incredible innovations for indigenous natural resources management, which cannot be brought from elsewhere.

Eco-Zero Weeding: The eco-zero weeding which acts as panacea shrine for agriculture by bringing unimaginable increase in yield and reducing environmental pollution problems. Table 1 gives detailed description of areas of benefits viz: Beneficial effect on agricultural crops; Beneficial effect on land resources; reduction in energy input; effect on economic gains; beneficial effects on environment; benefits to individual farmers and farming communities and aiding to public governance. Over and above all it is non-monetary input involving scientific technology. Several publications (Yadav 2017b, 2018a,b,c, Yadav RC and Yadav LM, 2017) [2-7] support this incredible genius innovation, where the scientific wisdom has been brought at the world scale, replacing alternative agriculture practices of weed management viz. either, manual or mechanical or even weedicides have been tried and practiced producing lot of side adverse effects [8-12]. 
Physical Science \& Biophysics Journal

\begin{tabular}{|c|c|c|c|c|c|c|}
\hline $\begin{array}{c}\text { Extent of } \\
\text { Reduction in } \\
\text { Loss }\end{array}$ & $\begin{array}{l}\text { Nature of } \\
\text { Loss }\end{array}$ & $\begin{array}{l}\text { Adverse } \\
\text { Function }\end{array}$ & $\begin{array}{l}\text { Eco zero } \\
\text { Weeding }\end{array}$ & Positive Function & Beneficial Effects & $\begin{array}{l}\text { Extent of } \\
\text { Benefits }\end{array}$ \\
\hline$(1)$ & $(2)$ & (3) & $(4)$ & (5) & $(6)$ & $(7)$ \\
\hline- & - & - & 0 & + & + & + \\
\hline \multicolumn{7}{|c|}{ Beneficial Effect on Agricultural Crops } \\
\hline Extent & $\begin{array}{l}\text { Reduction in } \\
\text { crop losses }\end{array}$ & $\begin{array}{l}\text { Reduction in } \\
\text { weed growth }\end{array}$ & $\begin{array}{l}\text { Suppressed } \\
\text { weed stunted } \\
\text { growth }\end{array}$ & $\begin{array}{l}\text { Reduction in } \\
\text { weeds }\end{array}$ & $\begin{array}{l}\text { Reduction crop } \\
\text { yield loss }\end{array}$ & Extent \\
\hline-43 & Wheat & \multirow{3}{*}{ No weeding } & \multirow{3}{*}{$\begin{array}{l}\text { Eco zero } \\
\text { weeding }\end{array}$} & $\begin{array}{l}\text { Nitrogen fixation } \\
\text { and eco zero } \\
\text { weeding }\end{array}$ & Wheat & $\begin{array}{l}-31(\mathrm{i}) \\
-12(\mathrm{ii})\end{array}$ \\
\hline-36 & Mustard & & & & Mustard & $\begin{array}{l}-28(\mathrm{i}) \\
-16(\mathrm{ii})\end{array}$ \\
\hline-24 & Linseed & & & & Linseed & $\begin{array}{l}-14(\mathrm{i}) \\
-7 \text { (ii) }\end{array}$ \\
\hline \multicolumn{7}{|c|}{ Beneficial Effect on Land Resources } \\
\hline & & & & Increase in LER & \multicolumn{2}{|c|}{$\begin{array}{l}\text { LER Increased, } \\
\text { Economic return , crop quality } \\
\text { improved } \\
\end{array}$} \\
\hline & & & & $\begin{array}{c}\text { Increase in } N \\
\text { fixation }\end{array}$ & \multicolumn{2}{|c|}{ Increase in protein uptake } \\
\hline & & & & $\begin{array}{l}\text { Eliminate Earth } \\
\text { overshoot }\end{array}$ & \multicolumn{2}{|c|}{ Over comes earth overshoot } \\
\hline & & & & $\begin{array}{l}\text { Reduction in land } \\
\text { degradation }\end{array}$ & \multicolumn{2}{|c|}{$\begin{array}{l}\text { Increased soil health fosters high } \\
\text { yield of subsequent crops }\end{array}$} \\
\hline \multicolumn{7}{|c|}{ Reduction in Energy Input } \\
\hline & & & & $\begin{array}{l}\text { Reduction in } \\
\text { tillage }\end{array}$ & \multicolumn{2}{|c|}{$\begin{array}{l}\text { Number of ploughing reduced, } \\
\text { secondary tillage eliminated. }\end{array}$} \\
\hline & & & & $\begin{array}{l}\text { Eliminates } \\
\text { drudgery of } \\
\text { weeding }\end{array}$ & \multicolumn{2}{|c|}{$\begin{array}{l}\text { Will enhance efficiency of zero } \\
\text { tillage }\end{array}$} \\
\hline \multicolumn{7}{|c|}{ Effect on Economic Gains } \\
\hline & & & & Energy saving & \multicolumn{2}{|c|}{$\begin{array}{c}\text { Cost of tillage and other cultivation } \\
\text { reduced }\end{array}$} \\
\hline & & & & $\begin{array}{c}\text { Time saving, high } \\
\text { output of crop and } \\
\text { better quality }\end{array}$ & \multicolumn{2}{|c|}{$\begin{array}{l}\text { Increased in commodity and quality } \\
\text { will enhance economic gain }\end{array}$} \\
\hline \multicolumn{7}{|c|}{ Beneficial Effects on Environment } \\
\hline $\begin{array}{l}+\mathrm{N}_{2} \mathrm{OGHG} \\
\text { emission }\end{array}$ & & & & $\begin{array}{c}\text { Reduction of } \\
\text { Nitrous oxide } \mathrm{N}_{2} \mathrm{O}\end{array}$ & \multicolumn{2}{|c|}{$\begin{array}{c}\text { GHG } \mathrm{N}_{2} \mathrm{O} \text { emission reduced, ozone } \\
\text { depletion risk reduced, acid rain } \\
\text { problem reduced, green house gas } \\
\text { effect reduced. }\end{array}$} \\
\hline
\end{tabular}




\begin{tabular}{|l|l|l|l|c|c|}
\hline & & & $\begin{array}{c}\text { Assured } \\
\text { sustainable and } \\
\text { enhance yield }\end{array}$ & $\begin{array}{c}\text { Better economic gain and gainful } \\
\text { agriculture, increase in happiness, } \\
\text { stable mind etc. no revert to suicide }\end{array}$ \\
\hline & & & Aiding to Public Governance \\
\hline & & $\begin{array}{c}\text { Better and } \\
\text { effective } \\
\text { governance }\end{array}$ & $\begin{array}{c}\text { Satisfied hunger free gentry, } \\
\text { progressive out look and riot free } \\
\text { country }\end{array}$ \\
\hline
\end{tabular}

Table1: Reduction in losses and enhancement in benefits by manoeuverable eco- zero weeding agriculture.

Various aspects enumerated about the manoeuverable zero weeding agriculture support positive aspects of the new innovative technology. It has no disadvantage or any limitation. The most important and prominent aspect is that it is a non-monetary input technology to bring improvement in any land limiting agrarian country without any extra budget and special skilled input of man and machineries. It reduces runoff and land degradation due to residual nutrient in soil and quickly restored soil health. It reduces losses or negative aspects and pushes them to produce beneficial effects; hence it is proven as a panacea technology. As it brings multiple cornered benefits and stock of gains in all aspect in agriculture; it is very appropriate case of panacea shrine for agriculture, not for India alone but all agriculture world over. When the tangible and non tangible benefits are summed up it will eliminate all discrepancies in agriculture, reduce need of fertilizer and will not demand extra special implements. That means technology is ready for people's demonstration and promoting adoption.

Universally Applicable Wheat Production Technology for Eliminating Global Hunger: The author had been working on nature based agricultural solutions in agriculture since 2013 and produced innovative researches on various aspect of agriculture under smart alive and enthusiastic (RACY) nature agriculture. Some innovations have been demonstrated on farmers' field in the paddy wheat cropping patter Yadav [6]. The yield responses are surpassing the yields acquired in world agriculture. This study presents a nature based universally applicable technology for production of unimaginable yield of wheat. The yield performance with still better crop variety and geographical situation of Karnal will enhance yield. Such enhancement in yield of crop at Karnal by innovative technology presented in this study will convince people believe and accept for their own adoption (Figure 1-2).

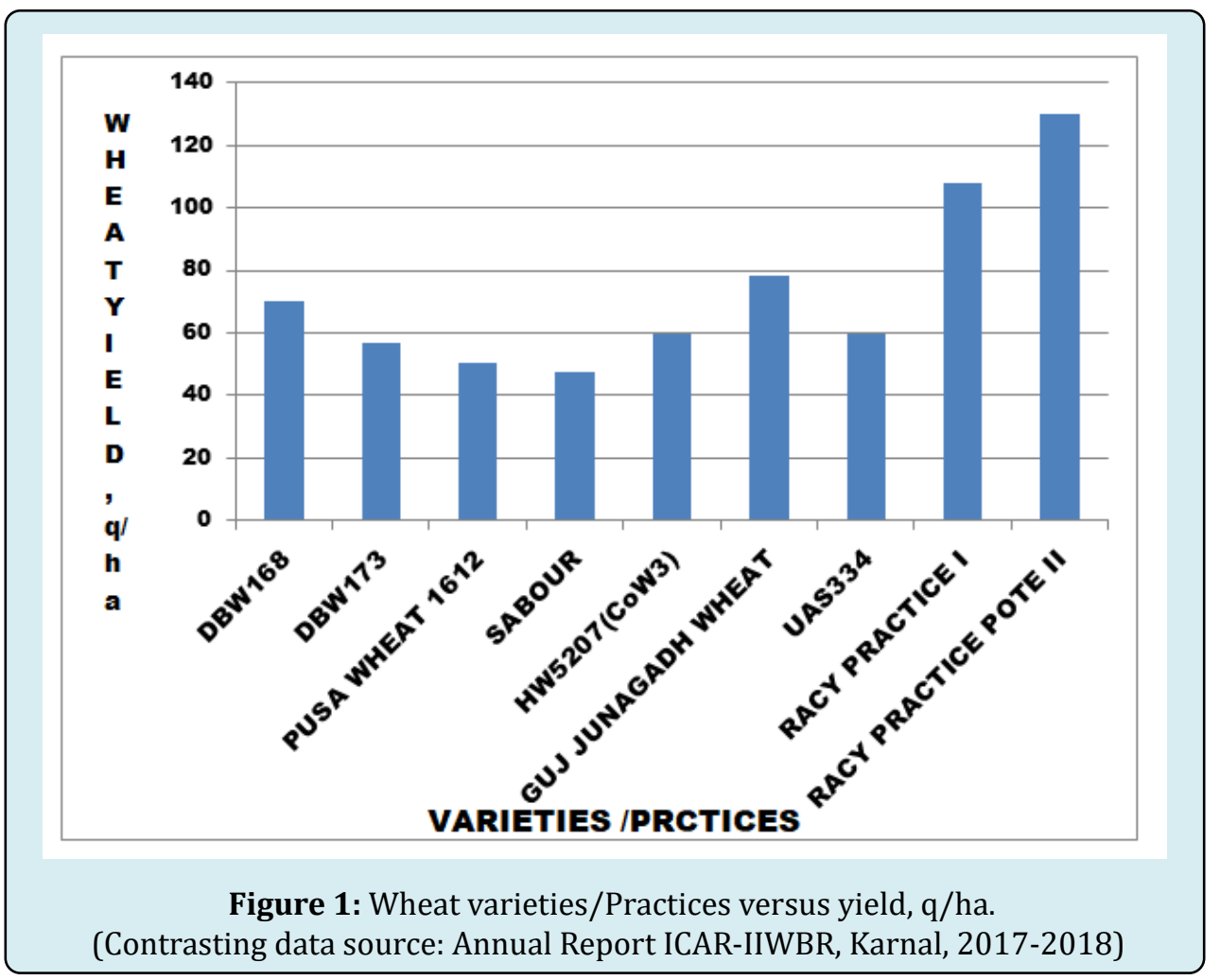

Yadav RC and Iadav J. Capitalizing Genius Albert Einstein's Idea for Reformation of Educational Systems for Producing Genius Gentry. Phys Sci \& Biophys J 2020, 4(1): 000141. 


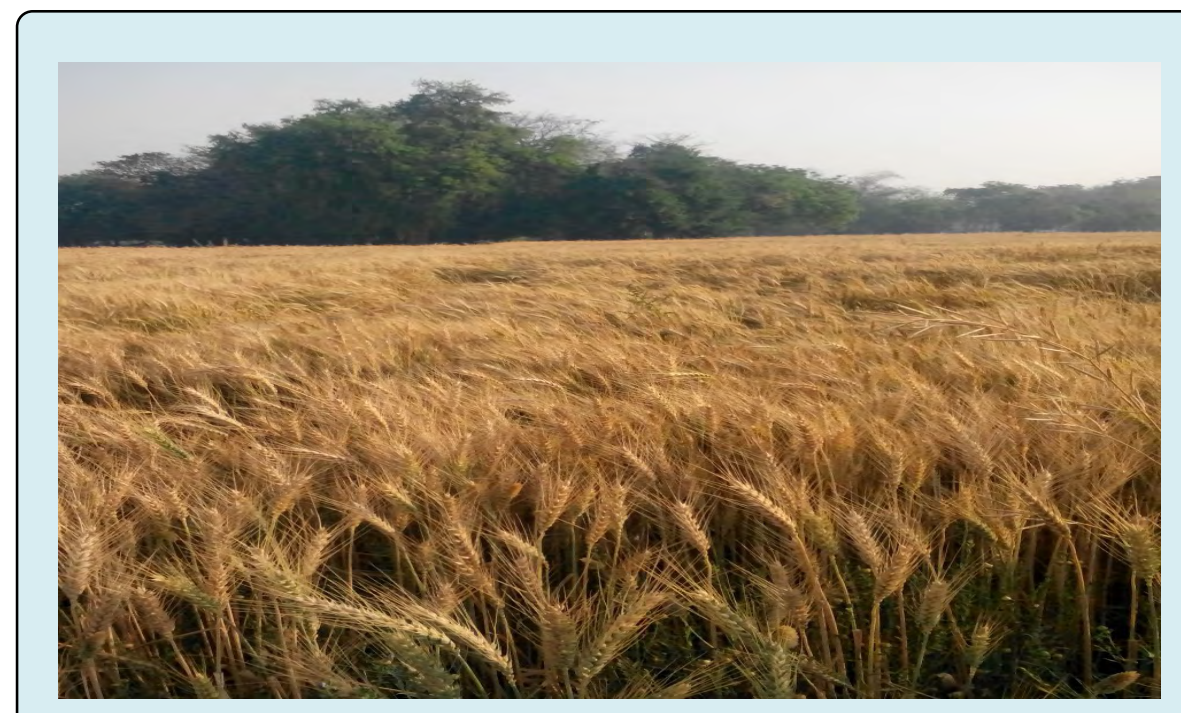

Figure 2: Photograph of field crop at maturity.

Based on the evidentiary substantiation it is concluded that innovative quantum (fixed mode) mechanics based production technology will perform still better than the results presented in this study. The yield performance of the technology will be more successful that will build confidence in wheat cultivation in India and rest part of world agriculture. Thus, it will produce food for present and posterity when land resources become scarce with multiplicity of land diversifications and development of adversity of climate change.

The example cases presented here in the present study sufficiently substantiated that long term living with problem enables development of genius way of overcoming it and finding solution as observed and opined by genius Albert Einstein. This lesson enables one to accept it and make suitable reformations in education system with solid footing.

\section{Implementation of the Module}

The solid foundation based reformation will be easy to implement because modality of its operation operando had been clearly elaborated. It needs adoption and motivating the people engaged in education systems. The system will bring uniform strategy of education development and free from any gender biasness. The development will create equal opportunity for all genders and no disparity for any caste and religion. Thus, it will be a wonderful development in bringing genius gentry and good harmony among people. The prosperity and sufficiency of livelihood would enable development of visionary aptitude and generous nature of the gentry. This will facilitate good public governance, stable market and control of price rise.

\section{Discussion}

\section{Substantiation of the Hypothesis}

The study did set out a hypothesis of living with any problem for long time to enable develop some genius solution as opined by genius Albert Einstein. This fact has been realized and a basic professional course of ITI is reformed to have final examination at the end of year. This pattern enables keep subject revised time and again that will make deep impressions in the mind, which will inspire to think and make some kind of discovery. The ITI is low level professional course which is created to train gray or blue color working technical hand of category I. The course is highly practical but as intake level course, largely high school pass students intake, it induces interest and creates mind strong to carryout practical and understand theory, This fact make the course interesting to the candidates and their knowledge and training becomes highly useful in their professional career.

Although there are different types of degree, PG and Higher learning course including diploma having trimester, semester and annual examinations. These course durations being shortest, to longest as annual must have some different degree of impression on memory. Long duration course should have deeper impact and should remain in memory. Each of courses and institutions has different duration and has their own justification for what they are doing and the benefits they must be gaining. There has been different success in competitive examination scores. However no such systematic evaluation was conducted and neither such evaluation expected to exist as this innovative hypothesis is a new development in the present study. In order to 
substantiate the new hypothesis two example cases on incredible innovations viz Eco zero weeding and universally applicable wheat production technology for producing unimaginable yield of wheat, which had been developed after long experience and continued working with keen interest that fulfilled remaining with problems. The both the example case create innovative indigenous natural resources management which bring very incredible solutions in agriculture with multiple benefits and universally applicable production technology to eliminate global hunger. Thus, later two example cases substantiate the hypothesis for degree and higher learning courses. Thus, the hypothesis is sufficiently substantiated and presents logically mature case for reformation of duration and examination patterns of education to produce genius gentry.

\section{Implication of Biography of Genius Albert Einstein}

Albert Einstein was a healthy child born to happy parents in Europe, where concepts of taking things occur in batter way than exists even today in India, in, general. So he had happy before birth and after birth childhood care and inspiring environment. That was time when he had opportunity to move with new developments. This indicates early i.e. before birth, childhood care and continuity in developing things keep ones' mind accept things, maintain interest and do some things better than what one has been doing and seeing. Thus, Albert had all opportunities to develop, analyze and think in developing environment. Thus, he had remained for long time, became genius. He opined that he lives with problem he foresees and finds solution to that. These are creations of development of genius gentry and harnessing outcomes of genius minds. Einstein's idea had been taken as hypothesis and sound basis is developed for reformation of education systems, which is base for developing genius gentry in any country. The new reformations in the education systems will enable make long contact with lesson and opportunity to think better with adequate knowledge. This will bring similar parallel results, the degree and sufficiency of quality of genius level may or may not develop to the extent of Einstein, but it is certain that genius people will always be efficient, productive and positive thinkers. The entire investment in education will be highly effective in building national prosperity of varying natures.

\section{Implication of Genius Wisdom in National Prosperity}

Genius gentry produce genius innovations and discoveries, which become intellectual property for the nation with genius gentry (Parkinson and Rustamji) [8,9]. The domain of discovery is open ended and it can go to any extent where mind and thinking can reach. Past President Dr A.P.J Abdul Kalam used to advise the young students to dream. This present research is going step ahead to how to produce genius gentry in the country by creating a system of education. The intellectual properties become basis for technological development, production and manufacturing process that provide employment and bring prosperity in nation as well as livelihood. Thus, genius gentry will always be necessary asset for any rich or poor country. The genius population will be performing their function in efficient way and country will make socio economic prosperity.

\section{Intellectual Property Prosperity and Their Use for Resources Development with Genius Gentry}

Innovations such as computer and information technology are highly transferable from countries where it gets developed to various user countries. It is evident from the widespread use of computers and Information technology in almost all countries of the world. There might be some degree of variation, but it is not because of any country's creation but because of affordability at first hand followed by education expansion of the commuters. Thus, natural resources development is clear cut indicator for assessment of indigenous intellectual property for any country. Genius gentry create such intellectual property and enable country's prosperity.

The indigenous natural resources differ from one place to other and from country to country. Their fore, incredible innovation presented in substantiation of the hypothesis is highly appropriate and convincing cases. The development of genius will create principle based innovation which will enable all countries use their country's resources for solving the problem. Thus, it will be real benefit of development of genius gentry in any country. This sufficiently justifies that the sound hypothesis and lesson on decisive theory serving as foundation and sustainability (Ramamrutham, 2008) for reformation of education system should be fast adopted [9].

\section{Implication of Theory and Practice on Development of Genius Gentry}

The present study has developed a hypothesis of opinion of genius Albert Einstein (Ardagh, 2000 and Hindustan $<$ 2017), substantiated to bring a solid foundation based scientific reformations in the educational systems. It has both components of theory and practice [11]. Both theory and practice have similar impacts. Theory has to be universally adopted and local practice should be developed to make some local corrections, if some short fall occurs. Thus study has brought a breakthrough for bringing new wave of making ongoing investments in education and development of genius 
gentry. The new genius generation would build better world as established by the cited examples of substantiation of the hypothesis. That means a new world will emerge with genius gentry.

Figure 3 presents status and roles of theory and practice and their implications on making policy tool for governance in any country. The present study has brought clear cut theory based on substantiated hypothesis of developing genius gentry, its application in practice for world over countries with educations of different countries and different sphere of developments, which will bring new world to come as effect of reformations in the educational systems. The genius gentry will produce intellectual property based prospects, as elucidated by the two glaring cases cited for substantiating the hypothesis. Thus, it demands bringing reformations in education system by broad theory developed in the present research and some improvement in shortfall by local practice. The Figure 3 clearly presents and support the theory that think global and act local. When reformations / modification will be practiced as per theory it will produce effect in country and globe for creating resources, sufficiency, sustainability (Ramamrutham, 2008), efficiency and impact (RSSEI).

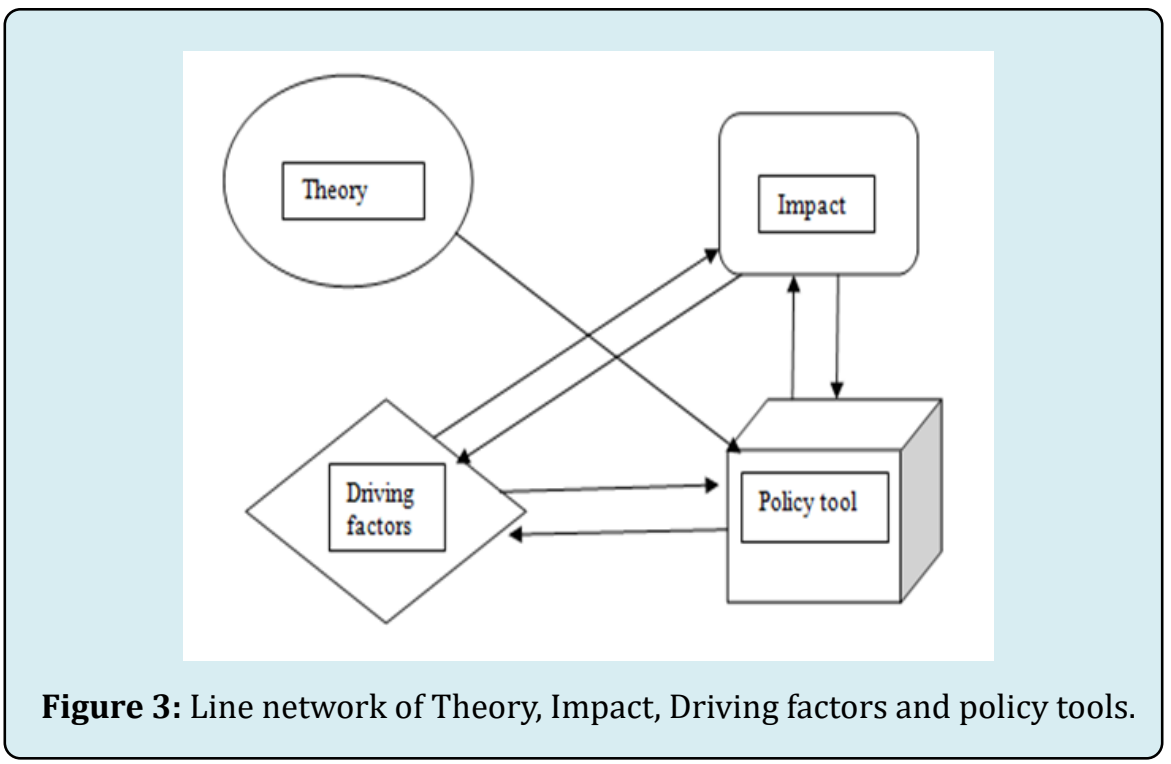

\section{Conclusion}

The present study created new hypothesis for capitalizing genius Albert Einstein's idea of remaining with problem for long time to develop solution and relevant substantiation led to bringing sound basis for bringing reformations in ongoing long time different modes of education in to sound footing. Irrespective of any duration viz trimester, semester or annual, the final examinations for the subject should be made on annual basis, at the end of year, this will enable revision and remain in contact with the subjects for long time that will create deep impact on memory and enable development of genius gentry. The genius gentry will create new world in time to come. The reformation goes with ongoing system and does not disturb it or involve huge budget, but it improves systems resource, sufficiency, sustainability, efficiency and impact (RSSEI).

\section{References}

1. Ardagh P (2000) Wow-Discoveries that changed the world. Macmillan Children's Books, pp: 112.
2. Yadav RC (2017b) Practice for intercropping and making shortfalls in pulse productivity and reduction of greenhouse gas nitrous oxide. Archives in Chemical research 1(2): 10 .

3. Yadav RC (2018a) Development of universal ultimate green chemistry and eco agriculture for sustainable productivity. In: Singh V, Yadav S, Yadava R (Eds.), Water Resources management. Water Science and technology Library. Vol 78, Springer, Germany.

4. Yadav RC (2018b) Eco-zero weeding: a wow incredible innovation for altering things around us and India inaction. World J Agri Research 6(3): 94-104.

5. Yadav RC (2018c) Nano biotechnology for enhancing agri productivityto elimiminate global hunger. Bio-Core: International J Bio Technology 3(4).

6. Yadav RC (2018d) Nature based production technology for wheat. Submitted ICAR News Letter. Directorate of publications of agriculture, KABI, Pusa campus, New Delhi. 
7. Yadav RC, Yadav LM (2017) New innovative technology for producing exemplary yield of garlic and onion. Innovative techniques in Agriculture 1(4): 192-204.

8. Hindustan (Hindi) (2017) Three rules for way of life. Hindustan (Hindi) Daily News.

9. Parkinson CN, Rustomji MK (1993) Realities in management. India Book House Pvt Ltd, pp: 80-103.

10. Ramamrutham S (2008) Hydraulics, Fluid Mechanics, and Hydraulic Machines. $8^{\text {th }}$ (Edn.), Dhanpat Rai Publishing Co., New Delhi, pp: 252.

11. Yadav RC (2014) Biological nitrogen harvesting from aquatic ecosystem-A new scientific vision. Fish Aqua J 5(3): 1-8.

12. Yadav RC (2017a) Eco-zero weeding agriculture to produce exemplary yield of onion- A corroborative study. Innovative Techniques in agriculture. Scientia Ricerca 1(5): 234-245. 